\title{
New myxomycete records from \\ the Canary Islands
}

\section{Ángela López-Villalba", Gabriel Moreno'}

\author{
Keywords: Canary Islands, Myxomycetes, \\ new records, SEM. \\ 1 Dpto. Ciencias de la Vida (Botánica), \\ Universidad de Alcalá, 28805 Alcalá de Henares, \\ Madrid, Spain \\ * Corresponding author: \\ angelalv92@gmail.com \\ Article info: \\ Received: 24 July 2020 \\ Accepted: 03 September 2020 \\ Published online: 21 September 2020 \\ Corresponding Editor: Nikki Heherson A. Dagamac \\ Assistant Editor: Oleg Shchepin
}

\begin{abstract}
The volcanic Canary Islands constitute a biodiversity hotspot. Although our knowledge of the native flora and fauna species is extensive, the myxobiota of these islands is not so well-known. For this reason, we provide herein eight new records for the checklist of Canarian myxomycetes with accurate descriptions and macro- and microphotographs. The specimens were collected in Tenerife during the months of November and December 1987. All of them are new to the Canary Islands.
\end{abstract}

\section{Introduction}

Myxomycetes are a monophyletic group within the Amoebozoa (Cavalier-Smith et al. 2015, Leontyev et al. 2019) that appear in diverse habitats that range from tropical inflorescences (Schnittler \& Stephenson 2002) to plant debris at the borders of melting snowbanks (Stephenson et al. 2007, Schnittler et al. 2015, Moreno et al. 2018a). 
The distinctive characteristics of the Canary Islands are their volcanic origin and the high number of native species they host. The isles, which originated from submarine eruptions, are far from Europe and Africa, but they have adapted species of plants and animals, which are closely related to some of the continent inhabitants. Most of the known species within these groups are protected there because of their endemicity (Martín-Esquivel et al. 2005). Otherwise, fungi and microorganism diversity are less known, as well as aquatic species (Machado 1998).

Specifically, Tenerife is not only the largest island of the archipelago (total area of $2034.38 \mathrm{~km}^{2}$ ), but also the one with the highest number of different ecosystems due to its elevational gradient. This last factor also contributes to the establishment of a different climate pattern between the north and the south of the isle (Arco Aguilar \& Rodríguez Delgado 2018). The ecosystems vary from the dunes found at the beaches, to the humid laurisilva forests at the northeast of the island, the arid areas towards the centre, and, finally, the Canarian pine forests and the high peak of the Teide (3718 m).

The diversity and endemicity of plants inhabiting the island may suggest that the diversity of myxomycetes found there also would be high. But, despite the interesting facts mentioned, studies focused on myxomycetes in Canary Islands are scanty and relatively old (Lado et al. 2003, Beltrán-Tejera et al. 2004, 2010), with an exception of the discovery of nivicolous myxomycetes in the Teide National Park (Moreno et al. 2018b). The last species checklist was done in 2009 (Beltrán-Tejera 2009), hence it was used as a guide to establish the new records for the current study.

Consequently, the main purpose of this paper is to increase the number of myxomycetes known from the Canary Islands, providing eight new records with accurate descriptions and photographs of the specimens.

\section{Material and methods}

The material was collected by Enric Gràcia (University of Barcelona) at different localities on the island of Tenerife. The specimens were studied at the
University of Alcalá de Henares (Madrid) and they will be returned to and deposited in Centro de Documentación de Biodiversidad Vegetal (University of Barcelona).

Semi-permanent slides were prepared with Hoyer's medium. The diameter of the spores includes the surface structures, such as spines or warts. Light microscopy (LM) was carried out with a Nikon Eclipse 80i microscope. Scanning Electron Microscopy (SEM) studies and micrographs were performed with a Zeiss DSM-950 microscope. We followed the methodology described in Moreno et al. (2019) for studying the specimens by SEM. The terms established by Rammeloo $(1974,1975)$ are followed herein. Nomenclature follows Lado (2005-2020).

\section{Results}

\section{Craterium concinnum $\operatorname{Rex}$}

Fig. $1 \mathrm{a}-\mathrm{c}$

SPECIMENS EXAMined: Tenerife, Santa Cruz de Tenerife, Los Realejos, Palo Blanco-Llanadas, 28.365743, -16.582838, $600 \mathrm{~m}$, on cupules of Castanea sativa, 29/11/1987 (EG5442).

Sporocarps stalked, $0.5-0.8 \times 0.2-0.5 \mathrm{~mm}$. Peridium forming a crustaceous cup, thick, reddish-brown, with white edges at the top, with a fragile and pale brown lid. Stalk dark brown to black. Capillitium consisting of brownish nodules which sometimes join at the centre of the sporotheca to form a pseudocolumella. Spores globose to subglobose, brown, 8-10 $\mu \mathrm{m}$ diam., with warts. Under SEM the ornamentation of the spores consists of prominent and densely arranged bacula.

Remarks. - This species is usually found on chestnut burrs, as Rex (1893) indicated in the original description. This preference was lately repeated by Lister (1925) and Martin \& Alexopoulos (1969), although they also noted its appearance on other substrates, such as moss or wood, respectively. Macroscopically, the closest species is Craterium minutum (Leers) Fr., which can be distinguished by the larger and deeper sporangia $(0.75-1 \times 1-1.5 \mathrm{~mm})$, the yellow peridium with yellow edges and a brown 

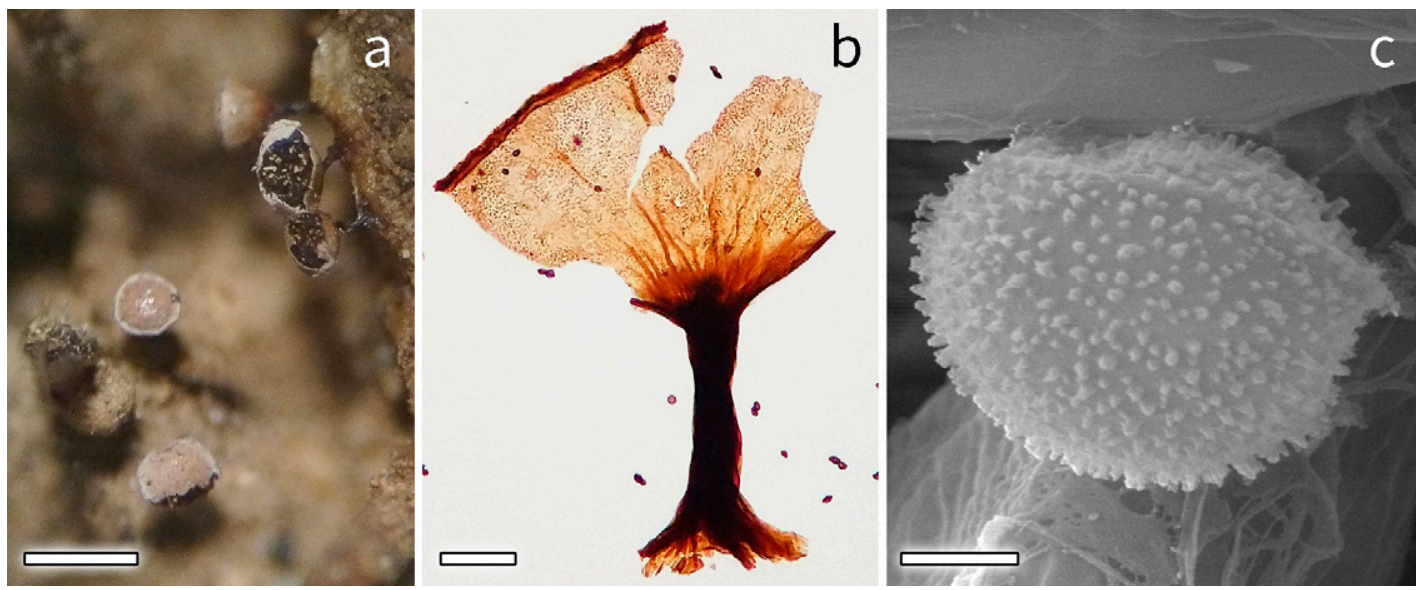

Fig. 1 Craterium concinnum Rex EG5442: a. Sporocarps, b. Details of the stalk and peridium, c. Spore. Scale bars: $a=0.5 \mathrm{~mm}, \mathrm{~b}=0.1 \mathrm{~mm}, \mathrm{c}=2 \mu \mathrm{m}$.

lid, the red to orange stalk, and the white nodules of the capillitium (Moreno-Gámez 2016).

\section{Diderma rufostriatum Nann.-Bremek. \& Lado \\ Fig. 2 a-f}

SPECIMENS EXAMINED: Spain, Tenerife, La Orotava, Aguamansa, 28.361572, -16.500114, $1100 \mathrm{~m}$, on bark and leaves of Eucalyptus sp., 13/12/1987 (EG5865, EG5867, EG5872, EG5890).

Sporocarps sessile or with very short stalks, 0.8-1.1 mm diam. Peridium triple; outer layer crustose, pink, with brown spots on top that merge together to create lines on the basal part; medium layer white, with globular crystals of calcium carbonate; inner layer membranous, iridescent and translucent. Stalk (if present) short, concolorous with the peridium. Hypothallus white. Pseudocolumella hollow, orange, filling half of the sporotheca. Capillitium with sinuous, thin threads $(0.5-1 \mu \mathrm{m}$ diam.), emerging radially from the pseudocolumella. Spores globose to subglobose, violaceous brown, 8-10 $\mu \mathrm{m}$ diam., with very marked warts. Under SEM the ornamentation of the spores consists of bacula, sometimes joined into short crests.

Remarks. - This species is characterised by the pulvinate sporangia with brown spots on the top and brown lines towards the base. The colour of the peridium usually varies from pale pink to pale ochraceous-pink or almost white (Nannenga-Bremekamp \& Lado 1985, Sánchez \& Moreno 2014). In contrast, it is noteworthy that the Canarian specimens show a pink-brownish but not pale peridium with a concolorous, darker, circular area on the top.

These records could be the southernmost ones according to http://discoverlife.org, since this species has been collected at peninsular Spain, France, and the Netherlands. But there is one record listed in https://www.gbif.org/en/occurrence/2827476673 from Australia. We think that this record is doubtful due to the description given, which includes smaller spores (5-7 $\mu \mathrm{m}$ diam.) ornamented with fine warts, peridium double, and the presence of a brown-orange stalk sizing $0.75 \mathrm{~mm}$ long. A revision of the Australian sample should be performed to clarify whether it is the southernmost record of the species or not.

\section{Licea pygmaea (Meyl.) Ing}

Fig. 3 a-d

SPECIMENS EXAMINED: Spain, Tenerife, Santa Cruz de Tenerife, La Orotava, Aguamansa, La Caldera, 28.357770, -16.502295, $1200 \mathrm{~m}$, on fallen trunk of Pinus canariensis, 28/11/1987 (EG5399).

Sporocarps sessile, 0.05-0.4 mm diam. Peridium consisting of polygonal plates, shiny, dark 

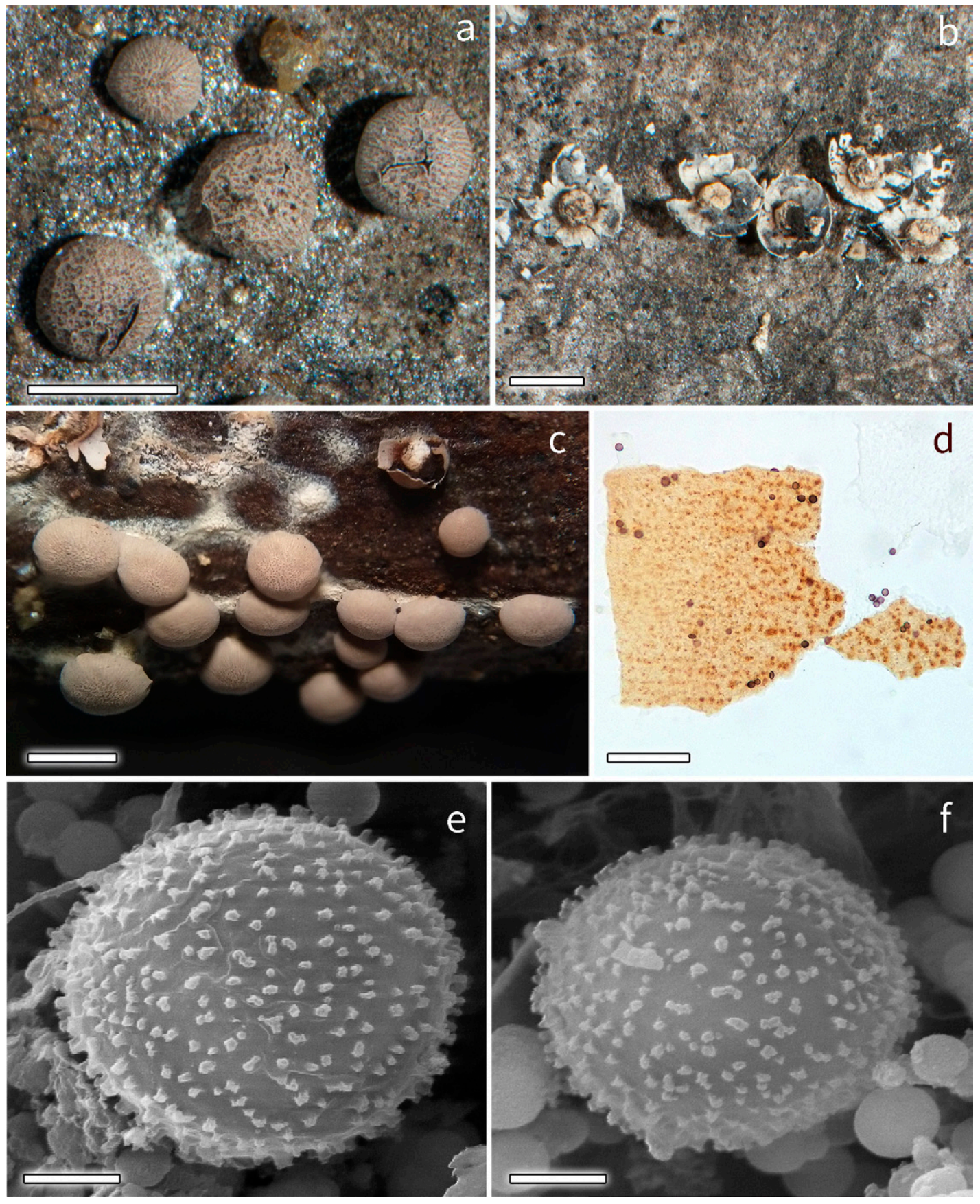

Fig. 2 Diderma rufostriatum Nann.-Bremek. \& Lado: a. Sporocarps EG5872, b. Details of the inner peridium and pseudocolumella EG5872, c. Sporocarps and pseudocolumella EG5865, d. Peridium under LM EG5890, e-f. Spores EG5442. Scale bars: $a-c=1 \mathrm{~mm}, d=0.1 \mathrm{~mm}, e-f=2 \mu \mathrm{m}$. 
brown. Capillitium absent. Spores globose to subglobose, reddish-brown on one half and yellowish-brown on the other, 10-12 $\mu \mathrm{m}$ diam., with small warts. Under SEM the ornamentation of the spores consists of dense and thick bacula.

Remarks. - This species usually goes unnoticed due to its small size. It is characterised by the dark colour of the peridium, varying from dark brown to black, with angular plates that join in shiny dehiscence lines. The spore mass is usually brown to reddish-brown and the spores under transmitted light fade from reddish-brown to yellowish-brown, size 11-15 $\mu \mathrm{m}$ diam., and show a double wall with a germination pore (Mitchell 1978).
Perichaena quadrata T. Macbr.

Fig. 4 a-e

SPECIMENS EXAMINED: Spain, Tenerife, Santa Cruz de Tenerife, Güímar, Puertito de Güímar, Punta de Güímar, 28.304395, -16.361891, 20 m, on fallen trunk of Euphorbia canariensis, 30/11/1987 (EG5476); Güímar, 28.312977, -16.401947, 200 m, on fallen leaves of Agave sp., 30/11/1987 (EG5489).

Sessile sporocarps to short plasmodiocarps as a result of the fusion of two sporocarps, convex, $0.3-1 \mathrm{~mm}$ diam., normally in groups. Peridium dark red-brown, shiny, somewhat iridescent, dehiscence as a flap, which allows to see the inner colour of the bright yellow spore mass at the edges. Capillitium
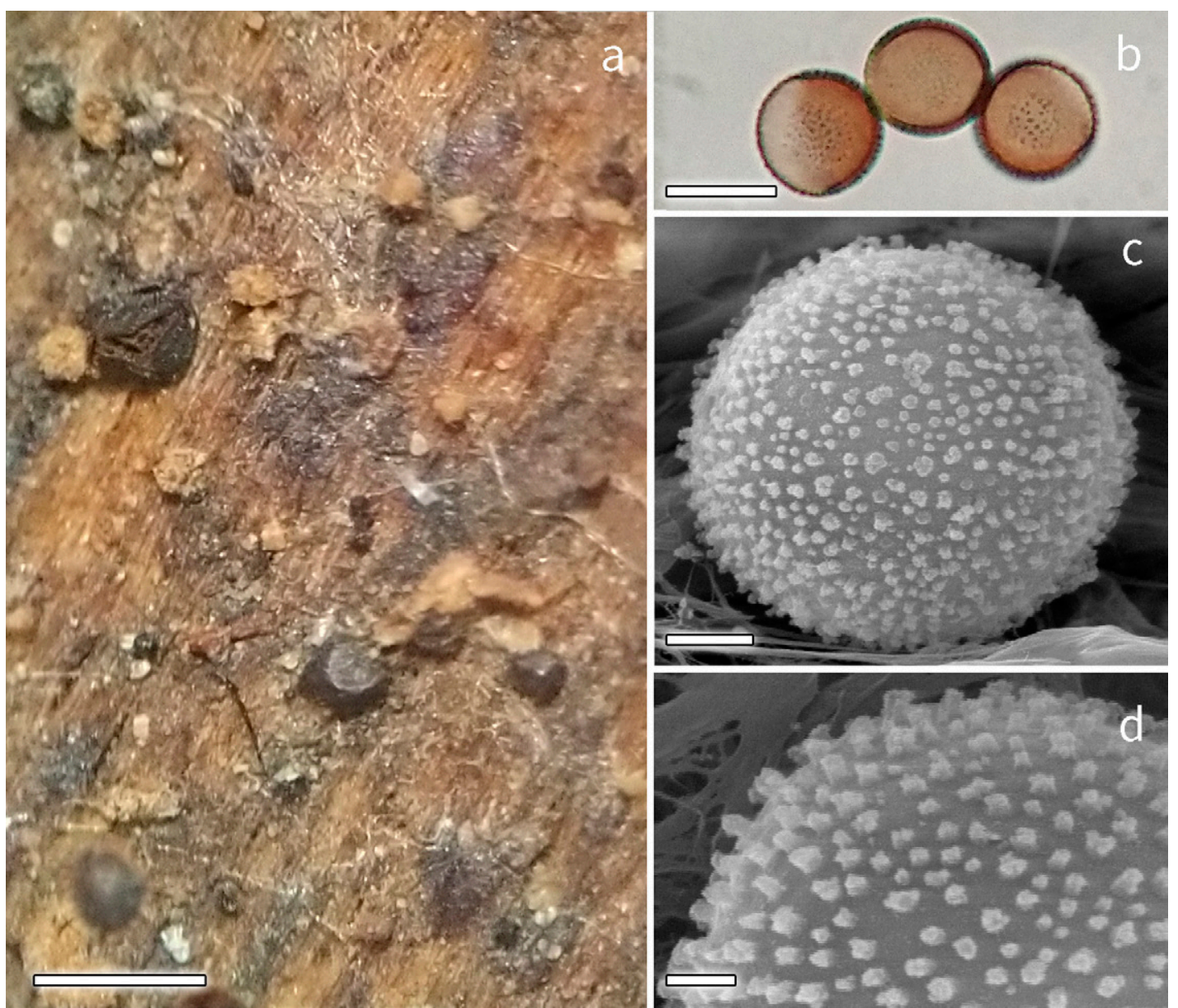

Fig. 3 Licea pygmaea (Meyl.) Ing EG5399: a. Sporocarps, b. Spores, c. Spore, d. Details of the spore ornamentation. Scale bars: $a=0.5 \mathrm{~mm}, b=10 \mu \mathrm{m}, c=2 \mu \mathrm{m}, \mathrm{d}=1 \mu \mathrm{m}$. 


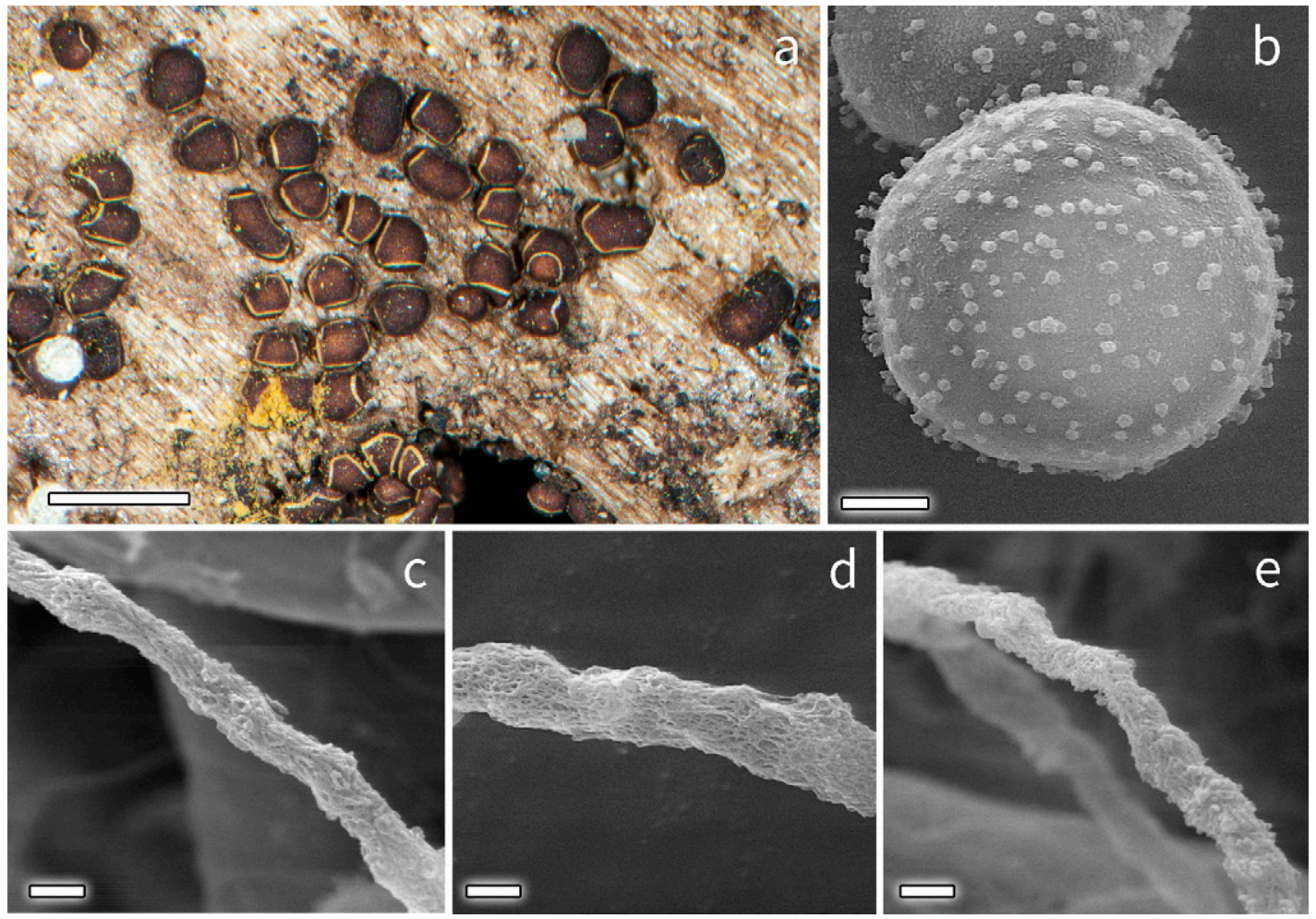

Fig. 4 Perichaena quadrata T. Macbr.: a. Sporocarps EG5476, b. Spore EG5476, c-e. Details of the capillitium (c and $e=E G 5489, d=E G 5476)$. Scale bars: $a=1 \mathrm{~mm}, b-c$ and $e=2 \mu \mathrm{m}, d=1 \mu \mathrm{m}$.

irregular, branching and anastomosing, threads yellow and abundant, 1.5-2.5 $\mu \mathrm{m}$ diam., with a reticulate pattern covering its surface, evident under SEM. Spores globose to subglobose, yellow, 9-10 $\mu \mathrm{m}$ diam., with warts. Under SEM the ornamentation of the spores consists of pila loosely and irregularly distributed.

Remarks. - This species is easily recognisable because of its rounded and convex sporocarps, sometimes with a tendency to form short plasmodiocarps, bright reddish-brown, threads of the capillitium irregular and covered with an evident reticulum under SEM, spores 9-10 $\mu \mathrm{m}$ diam.

Two similar species are Perichaena corticalis (Batsch) Rostaf. and P. depressa Lib. The first species (P. corticalis) can be distinguished by the larger spores (12-14 $\mu \mathrm{m}$ diam.) (Mitchell 1978, Lizárraga et al. 2015a) and the dehiscence occurring along a whole circular lid developed on the middle of the sporocarp.
On the other hand, Perichaena depressa develops flat and wider (0.5-1.5 mm diam.) (Mitchell 1978) sporocarps, and its spores are 8.5-10 $\mu \mathrm{m}$ diam., a range which overlaps with $P$. quadrata. Therefore, some authors (as Moreno et al. 2012) considered them as one very variable species. The first SEM studies focused on the differentiation of $P$. depressa and P. quadrata were done by Keller \& Eliasson (1992). The authors concluded that these species were two different ones, saying that $P$. depres$s a$ shows pitted and spinulose capillitium threads, whilst $P$. quadrata shows a low reticulum covering them. Other interesting studies including SEM micrographs supporting this opinion were made by Wrigley De Basanta et al. (2013) and Lizárraga et al. (2015a, 2015b). The last two papers include SEM micrographs of the inner peridium surface of $P$. quadrata, which also shows a reticulum. 

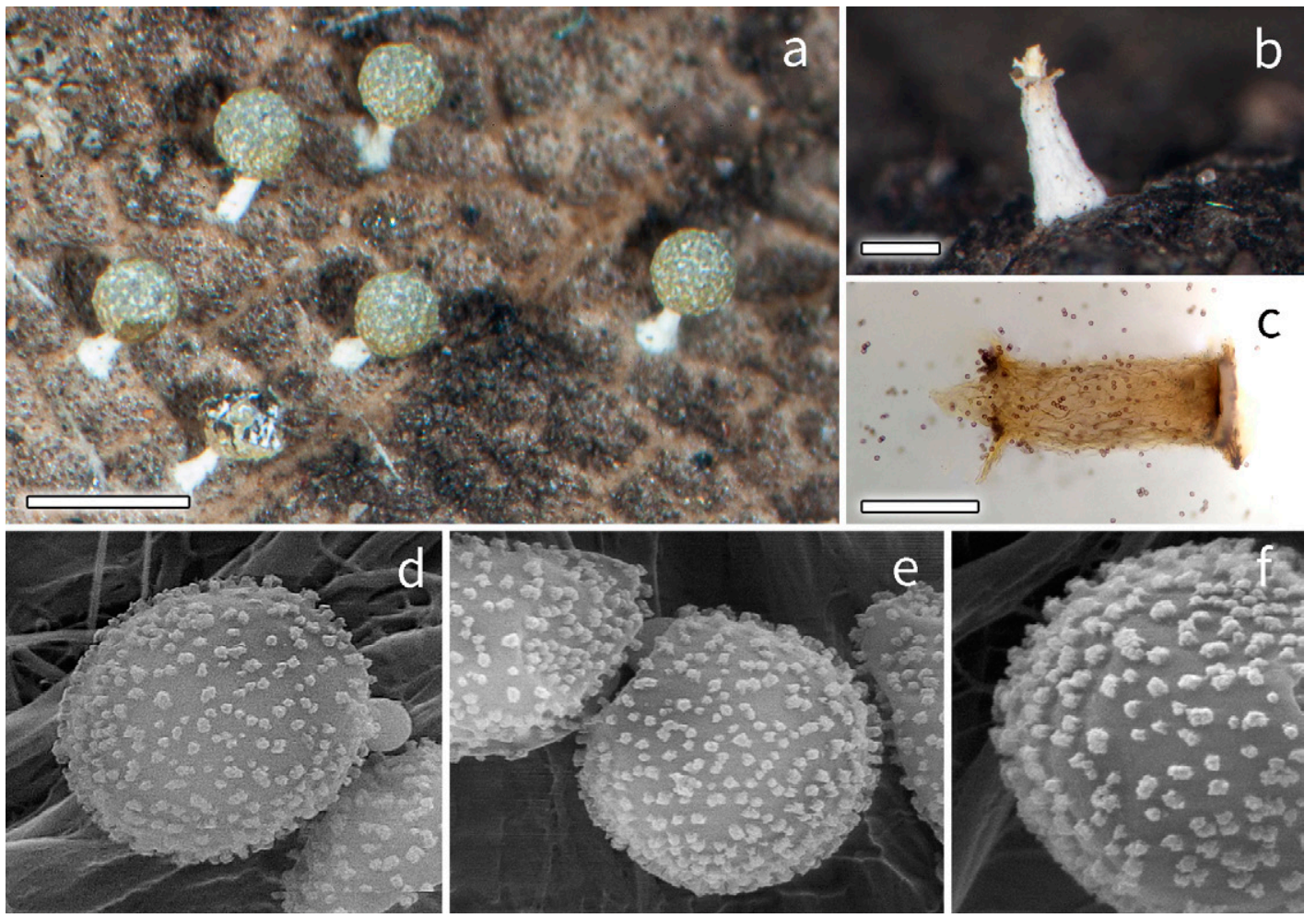

Fig. 5 Physarum melleum (Berk. \& Broome) Massee EG5351: a. Sporocarps, b-c. Details of the stalk and pseudocolumella, $\mathbf{d}$-e. Spores, $\mathbf{f}$. Details of the spore ornamentation. Scale bars: $a=1 \mathrm{~mm}, b-c=0.25 \mu \mathrm{m}, \mathrm{d}-\mathrm{e}=2 \mu \mathrm{m}, \mathrm{f}=1 \mu \mathrm{m}$.

Physarum melleum (Berk. \& Broome) Massee

Fig. 5 a-f

SPECIMENS EXAMINED: Spain, Tenerife, Santa Cruz de Tenerife, San Andrés, Taganana tunnel entrance, 28.547526, -16.203032, $560 \mathrm{~m}$, on fallen leaves of Myrica faya, 27/11/1987 (EG5345); ibidem, on fallen leaves of Rubus ulmifolius (EG5347, EG5348, EG5351).

Sporocarps stalked, $0.8-1 \times 0.4-0.6 \mathrm{~mm}$. Peridium membranous, iridescent, thin, pale yellow to pale brown in transmitted light, covered with a layer of yellow to orange calcium carbonate, fading into grey when old, and with some white external carbonate nodules. Stalk white, robust, carbonated. Pseudocolumella white, small, conical. Capillitium with white nodes of calcium carbonate, connected into a three-dimensional net by hyaline, short threads. Spores globose to subglobose, violaceous brown, 7-9 $\mu \mathrm{m}$ diam., with warts and darker groups of warts. Under SEM the ornamentation of the spores consists of densely and irregularly distributed bacula.

Remarks. - The main characters of this species are the yellow to orange sporotheca with grey shades, the small, conical, and white pseudocolumella, and the white, robust, striated, and carbonated stalk. Interesting macroscopic photographs were taken by Moreno et al. (2015), and they confirm our observations. This species is distributed worldwide (https://discoverlife.org).

Reticularia jurana Meyl.

Fig. $6 \mathrm{a}-\mathrm{e}$

SPECIMENS EXAMINED: Spain, Tenerife, Santa Cruz de Tenerife, San Andrés, punta de Los Órganos, 


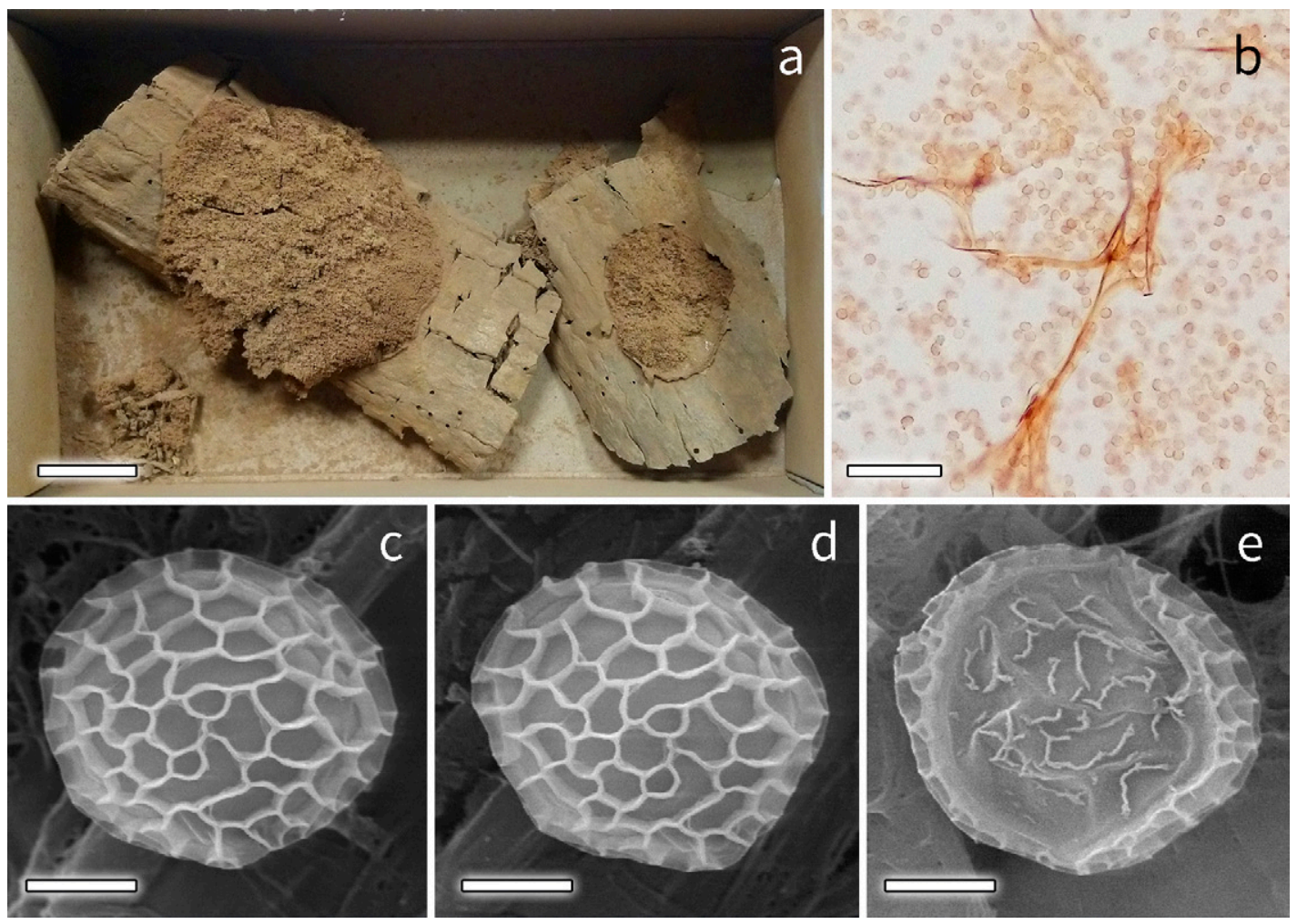

Fig. 6 Reticularia jurana Meyl. EG5324: a. Aethalia, b. Spores and pseudocapillitium, c-e. Spores. Scale bars: a = 1 $\mathrm{mm}, \mathrm{b}=50 \mu \mathrm{m}, \mathrm{c}-\mathrm{e}=2 \mu \mathrm{m}$.

28.512317, -16.179095, $160 \mathrm{~m}$, vegetal debris of Euphorbia regis-jubae, 27/11/1987 (EG5323, EG5324, EG5326).

Aethalium elongated, $0.5-3 \mathrm{~cm}$ length. Peridium forming a cortex, salmon pink to dark brown, sometimes coppery when mature. Hypothallus (if present) whitish. Pseudocapillitium filamentous, pale brown, abundant, creating a close, spongy net; threads thin (1-2 $\mu \mathrm{m}$ diam), branching, smooth, emerging from flat and perforated plates of different sizes connected to the base of the sporotheca. Spores globose to subglobose, pale brown, $6-8 \mu \mathrm{m}$ diam., half reticulated and half smooth. Under SEM the ornamentation of the spores is confirmed, showing a solid and raised reticulum.

Remarks. - The distinctive characteristics of this species are the large size, brownish colour which varies from pale brown to reddish or pinkish; and pseudocapillitium formed by thin, smooth, branched filaments resembling a sponge (Nannenga-Bremekamp 1991). These observations agree with those made by Moreno et al. (2017).

\section{Trichia crateriformis G.W. Martin}

Fig. 7 a-e

SPECIMENS EXAMineD: Spain, Tenerife, Santa Cruz de Tenerife, Anaga, Almáciga, TF-123, La Ensillada, 28.556208, -16.179804, $800 \mathrm{~m}$, on unknown fallen trunk, 27/11/1987 (EG5368, EG5369); Santa Cruz de Tenerife, La Orotava, Aguamansa, La Caldera, 28.357770, -16.502295, $1200 \mathrm{~m}$, on fallen trunk of Pinus canariensis, 28/11/1987 (EG5392); Santa Cruz de Tenerife, Los Realejos, Palo Blanco-Llanadas, Barranco los Viñaticos, 28.353084, -16.573920, $900 \mathrm{~m}$, on unknown fallen trunk, 29/11/1987 (EG5449); ibidem, on fallen trunk of Prunus lusitanica (EG5454). 
Sporocarps stalked, 1.3-3 × 0.5-1.5 mm. Peridium olive-brown, breaking easily and leaving a basal cup. Stalk dark brown to black, reaching half of the length of the sporocarp. Capillitium with elaters, 3-6 $\mu \mathrm{m}$ diam., ending in free, long, pointing tips, ornamented with a tight, smooth spiral, without spines or transversal marks. Spores globose to subglobose, olivaceous-yellow, 9-11 $\mu \mathrm{m}$ diam., with crests creating an irregular reticulum. Under SEM the ornamentation consists of raised crests creating short reticulated ridges. This kind of ornamentation was defined as cristate reticulate by Rammeloo (1974).

Remarks. - This species was previously determined as Trichia decipiens var. olivacea (Meyl.) Meyl. but, after revising the literature, neither T. decipiens var. olivacea nor T. crateriformis were reported from the Canary Islands. The drop-shaped sporocarps are characteristic, as well as the olive-brown colour of the peridium and the spore mass. The ornamentation of the spores is also unique within the genus. A detailed taxonomic study challenging the validity of this and other related species, including SEM micrographs, was made by Moreno \& Castillo (2013).

Trichia flavicoma (Lister) Ing Fig. 8 a-f

SPECIMENS EXAMined: Spain, Tenerife, Santa Cruz de Tenerife, La Orotava, Aguamansa, La Caldera, 28.357770, -16.502295, $1200 \mathrm{~m}$, on fallen leaves of Cistus symphytifolius, 28/11/1987 (EG5377, EG5378).

Sporocarps sessile or shortly stalked, $0.5-1 \times$ 0.2-0.6 mm. Peridium membranous, pale brown with darker lines which lately create breaking plates.

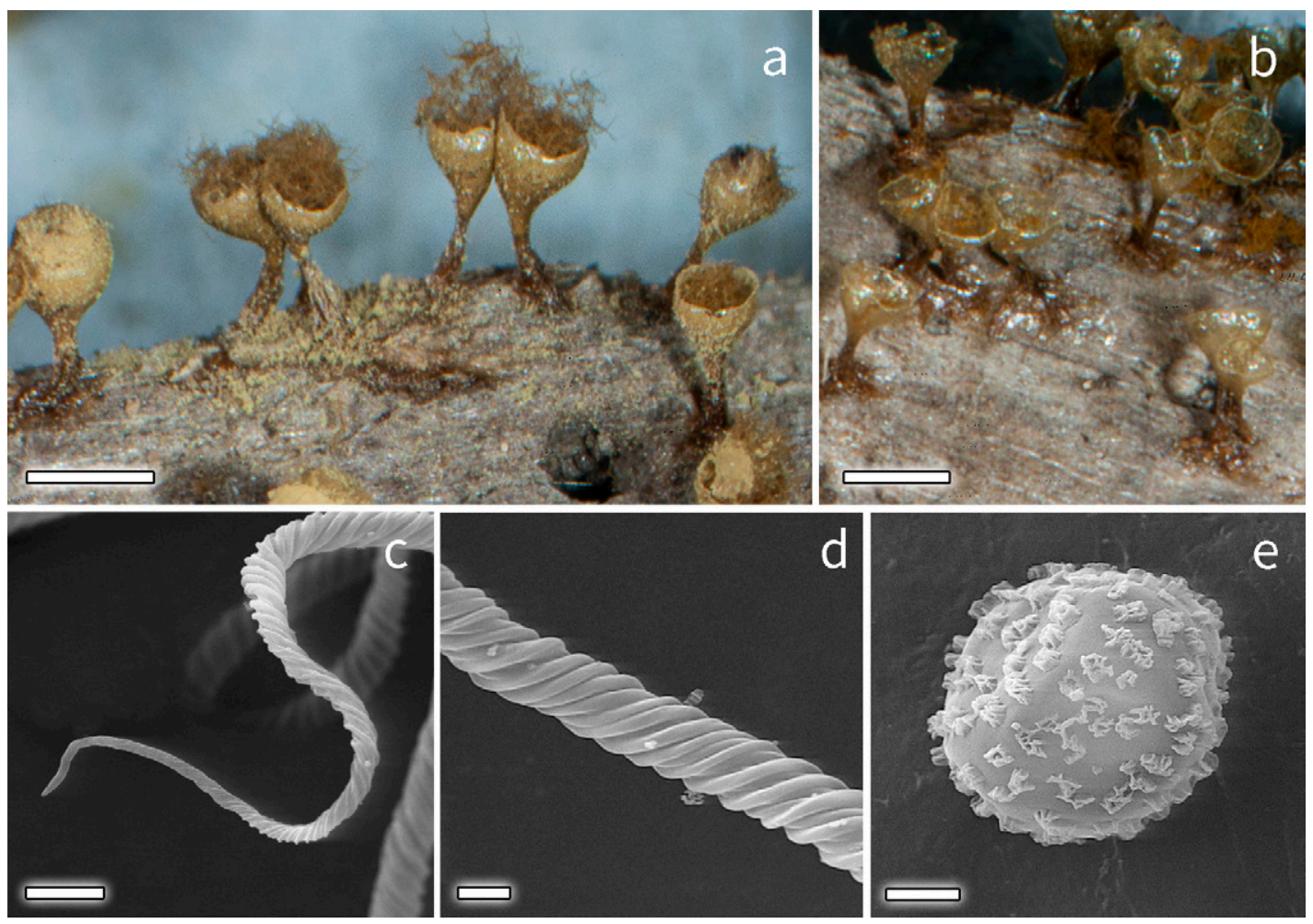

Fig. 7 Trichia crateriformis G.W. Martin EG5368: a. Sporocarps and capillitium, b. Detail of the opercular dehiscence of the sporocarps, $\mathbf{c}$. Elongated ending of one elater, d. Smooth spiral of the elater, e. Spore. Scale bars: $a-b=1 \mathrm{~mm}$, $c=5 \mu \mathrm{m}, \mathrm{d}-\mathrm{e}=2 \mu \mathrm{m}$ 

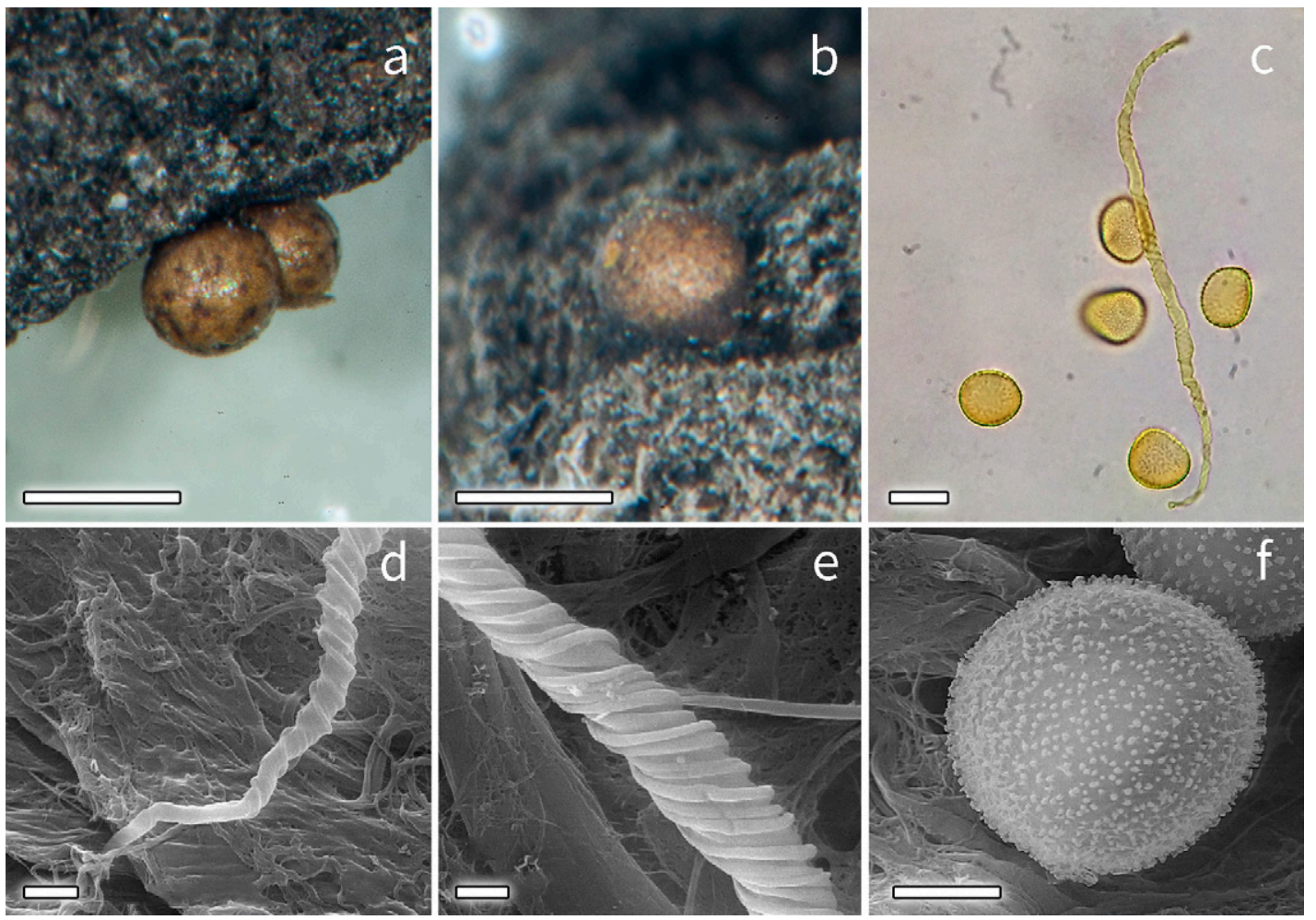

Fig. 8 Trichia flavicoma (Lister) Ing EG5368: a-b. Sporocarps, c. Capillitium and spores, d. Ending of one elater, e. Smooth spirals of the elater, $\mathbf{f}$. Spore. Scale bars: $a-b=0.5 \mathrm{~mm}, c=10 \mu \mathrm{m}, \mathrm{d}-\mathrm{f}=2 \mu \mathrm{m}$.

Stalk (if present) short, dark brown to black. Capillitium consisting of elaters, $3-5 \mu \mathrm{m}$ diam., ending in free, pointing tips, ornamented with a tight, smooth spiral, without spines or transversal marks, sometimes with swellings. Spores globose to subglobose, yellow, 10-15 $\mu \mathrm{m}$ diam., spiny. Under SEM the spore ornamentation consists of densely and regularly distributed bacula.

Remarks. - The specimens collected are not the typical ones with elongated stalks and a dark peridium, but the size of the spores, the elaters, and the paler dehiscence lines on the top of the peridium are characteristic. These forms are closer to those photographed by Bellido et al. (2014). Nannenga-Bremekamp (1991) indicated its occurrence on leaves, like our collections.

\section{Conclusions}

With the addition of the species provided within this paper, 187 species have been collected from the Canary Islands. Even though, our knowledge of the Canarian myxobiota is still scarce. The most surveyed one is Tenerife, and the samples collected during this study increase its known species. The remaining islands are El Hierro, La Palma, La Gomera, Gran Canaria, Fuerteventura, and Lanzarote. Little is known about them, apart from a few papers that focused on the description of one new species, but 
not on the overall myxomycetes diversity. Whilst some of them are extremely arid, mainly those nearest to the continent, others are extraordinarily humid, due to their oceanic climate. All things considered, it is foreseeable that not only rare or isolated species from the Cenozoic will appear, but also new species could be discovered in future expeditions to these amazing Islands.

\section{Acknowledgments}

We would like to thank Antonio Priego and José A. Pérez (Electron Microscopy Service, University of Alcalá), and Ángel Pueblas (Department of Drawing and Scientific Photography, University of Alcalá) for their invaluable help with SEM and the digital preparation of the plates. We thank Enric Gràcia for his kindness for lending us the samples he collected in Tenerife. As usual, thanks to Dr. Javier Rejos, curator of the AH herbarium, for his assistance and infinite patience managing the collections. We are also thankful to Dr. Steve Stephenson (University of Arkansas, USA) for reviewing the manuscript and his valuable comments, and to the unknown reviewers too. And last, but not the least, thanks to the staff of Karstenia, especially to Dr. Nikki Dagamac for inviting us to contribute to this interesting myxomycete special issue, and to the editor-in-chief, Dr. Riikka Linnakoski for her effort to make it possible.

\section{References}

Arco Aguilar, M.J. del \& Rodríguez Delgado, O. 2018. Vegetation of the Canary Islands. Springer International Publishing, Cham, Switzerland.

Bellido, F., Tapia, M., Paz, A. \& Lavoise, C. 2014. Nuevas aportaciones corológicas de Myxomycetes del orden Trichiales para la Península lbérica. Boletín Micológico de FAMCAL 9: 21-41.

Beltrán-Tejera, E. 2009. Fungi. Arechavaleta Hernández, M. Rodríguez Núñez, S. Zurita Pérez, N. \& García Ramírez, A. (eds.). Lista de Especies Silvestres de Canarias Hongos, Plantas y Animales Terrestres, 25-70.

Beltrán-Tejera, E., Lado, C., Barrera, J. \& González, E. 2004. Myxomycetes diversity in the laurel forest of Garajonay National Park (Canary Islands, Spain). Systematics and Geography of Plants 74(1): 159-173.
Beltrán-Tejera, E., Mosquera, J. \& Lado, C. 2010. Myxomycete diversity from arid and semiarid zones of the Canary Islands (Spain). Mycotaxon 113: 439-442.

Cavalier-Smith, T., Fiore-Donno, A.M., Chao, E.E., Kudryavtsev, A., Berney, C., Snell, E.A. \& Lewis, R. 2015. Multigene phylogeny resolves deep branching of Amoebozoa. Molecular Phylogenetics and Evolution 83: 293-304.

Keller, H.W. \& Eliasson, U.H. 1992. Taxonomic evaluation of Perichaena depressa and $P$. quadrata based on controlled cultivation, with additional observations on the genus. Mycological Research 96: 1085-1097.

Lado, C. 2005-2020. An online nomenclatural information system of Eumycetozoa. Madrid. Real Jardín Botánico. CSIC. https://www.eumycetozoa.com

Lado, C., Mosquera, J., Estrada-Torres, A., Beltrán-Tejera, E. \& Wrigley de Basanta, D. 2003. Description and culture of a new myxomycete, Licea succulenticola. Anales del Jardín Botánico de Madrid 60: 3-10.

Leontyev, D. V., Schnittler, M., Stephenson, S.L., Novozhilov, Y.K. \& Shchepin, O.N. 2019. Towards a phylogenetic classification of the Myxomycetes. Phytotaxa 399: 209-238.

Lister, A. 1925. A monograph of the Mycetozoa. A descriptive catalogue of the species in the Herbarium of the British Museum ( $3^{\text {rd }}$ ed. Revised by G. Lister). British Museum Natural History, London.

Lizárraga, M., Moreno, G. \& Escobar-Zapata, S. 2015a. Myxomycetes del área urbana de Ciudad Juárez, Chihuahua, México. Boletín de la Sociedad Micológica de Madrid 39: 83-92.

Lizárraga, M., Moreno, G., Esqueda, M., Salazar-Márquez, C. \& Coronado, M.L. 2015b. Myxomycetes of Chihuahua (México) 4. Central plains of the Chihuahuan desert. Mycotaxon 130(4): 1073-1101.

Machado, A. 1998. Biodiversidad. Un paseo por el concepto y las Islas Canarias. Cabildo de Tenerife, Santa Cruz de Tenerife.

Martín-Esquivel, J.L., Marrero-Gómez, M. del C., Zurita-Pérez, N., Arechavaleta-Hernández, M. \& Izquierdo-Zamora, I. 2005. Biodiversidad en gráficas. Especies silvestres de las Islas Canarias. Gobierno de Canarias.

Martin, G.W. \& Alexopoulos, C.J. 1969. The Myxomycetes. University of lowa Press, lowa.

Mitchell, D.W. 1978. A key to the corticolous myxomycetes. Part I. Bulletin of the British Mycological Society 12(1): 18-42. 
Moreno-Gámez, J.F. 2016. Myxomycetes de la Sierra de Aracena IV. Micobotánica-Jaén 11: 111-179.

Moreno, G. \& Castillo, A. 2013. A comparative study of the types of three species of Myxomycetes: Trichia crateriformis, T. fallax var. olivacea and T. fernbankensis. Boletín de la Sociedad Micológica de Madrid 37: 85-98.

Moreno, G., Castillo, A., Deschamps, J.R., Giménez, G.A., Hladki, A.I. \& López-Villalba, Á. 2015. Critical revision of some Myxomycetes deposited in the Buenos Aires herbaria BAFC, BA and the Tucuman herbarium LIL. IV. Boletín de la Sociedad Micológica de Madrid 39: 129-140.

Moreno, G., Castillo, A., Deschamps, J.R. \& Hladki, A.I. 2012. Critical revision of some Myxomycetes kept at the Buenos Aires BAFC herbarium and Tucumán LIL herbarium. II. Boletín de la Sociedad Micológica de Madrid 36: 81-92.

Moreno, G., López-Villalba, Á. \& Castillo, A. 2019. Some nivicolous Myxomycetes from Colorado and New Mexico (USA) sent by Ted Stampfer. Boletín de la Sociedad Micológica de Madrid 43: 5-15.

Moreno, G., López-Villalba, Á., Castillo, A., Romanenko, K.O. \& Leontyev, D. V. 2017. Notes on some myxomycetes from Crimea (Ukraine). Mycotaxon 132(3): 649-663.

Moreno, G., López-Villalba, Á. \& Stephenson, S.L. 2018a. Notes on four taxa of nivicolous Myxomycetes from northwestern India. Boletín de la Sociedad Micológica de Madrid 42: 3-10.

Moreno, G., Sánchez, A., López-Villalba, Á., Monje, L. \& Castillo, A. 2018b. First records of nivicolous Myxomycetes for Teide National Park, Tenerife, Canary Islands. Boletín de la Sociedad Micológica de Madrid 42: 11-19.

Nannenga-Bremekamp, N.E. 1991. A guide to temperate Myxomycetes. Biopress Limited, Bristol.

Nannenga-Bremekamp, N.E. \& Lado, C. 1985. Notes on some Myxomycetes from Central Spain. Proceedings of the Koninklijke Nederlandse Akademie Van Wetenschappen Series C-Biological and Medical Sciences 88: 219-231.

Rammeloo, J. 1974. Structure of the epispore in the Trichiaceae (Trichiales, Myxomycetes), as seen with the scanning electron microscope. Bulletin de la Société Royale de Belgique 107: 353-359.

Rammeloo, J. 1975. Structure of the epispore in the Stemonitales (Myxomycetes) as seen with the scanning electron microscope. Bulletin du Jardin Botanique National de Belgique / Bulletin van de National Plantentuin van België 45: 301-306.
Rex, G.A. 1893. New North American Myxomycetes. Proceeding of the Academy of Natural Sciences of Philadelphia 45: 364-372.

Sánchez, A. \& Moreno, G. 2014. Myxomycetes del Parque Nacional de la Sierra de Guadarrama I. Boletín de la Sociedad Micológica de Madrid 38: 79-101.

Schnittler, M., Erastova, D.A., Shchepin, O.N., Heinrich, E. \& Novozhilov, Y.K. 2015. Four years in the Caucasus - observations on the ecology of nivicolous myxomycetes.

Fungal Ecology 14: 105-115.

Schnittler, M. \& Stephenson, S.L. 2002. Inflorescences of neotropical herbs as a newly discovered microhabitat for myxomycetes. Mycologia 94: 6-20.

Stephenson, S.L., Moreno, G. \& Singer, H. 2007. Notes on some nivicolous myxomycetes from Australia and New Zealand including the description of a new species of Lamproderma. Österreichische Zeitschrift für Pilzkunde 16: 11-23.

Wrigley De Basanta, D., Lado, C., Estrada-Torres, A. \& Stephenson, S.L. 2013. Biodiversity studies of myxomycetes in Madagascar. Fungal Diversity 59: 55-83. 